\title{
Utilization of Moringa Oleifera Powder for Combating Micronutrient Malnutrition
}

\author{
Sravya Seva ${ }^{1}$, Lakshmi $\mathbf{J}^{2}$, Lakshmi $\mathrm{K}^{3}$ \\ ${ }^{1}$ PG Student - Food Science and Nutrition, College of Community Science, Acharya N G Ranga Agricultural \\ University, Guntur, Andhra Pradesh, India \\ ${ }^{2}$ Professor and University Head, Food Science and Nutrition, College of Community Science, Acharya N G Ranga \\ Agricultural University, Guntur, Andhra Pradesh, India \\ ${ }^{3}$ Assistant Professor, Food Science and Nutrition, College of Community Science, Acharya N. G. Ranga Agricultural \\ University, Guntur, Andhra Pradesh, India
}

\begin{abstract}
Malnutrition is world health crisis. Nutrient deficiencies are highly common among adolescent girls as their diets contain low levels of nutrients. Four hundred and sixty two million people across the world are suffering from malnutrition. Nutritional anemia is one of the causes for malnutrition among adolescent girls. Replacing the missing nutrients through value addition or supplementation can help preventing micronutrient malnutrition. Green leafy vegetables are good sources of micronutrients. Dehydration is a value addition process. The major nutrient deficiencies can be taken care of by value addition of moringa powders by incorporating them into commonly consumed and most accepted food products. Value addition can increase the palatability and nutritive value of foods. In the present study, an attempt was made to develop and evaluate the products by incorporating moringa leaf powders at 5 per cent level. The prepared recipes were subjected to Organoleptic evaluation by using 9 point hedonic scale. The mean scores of the recipes for all the sensory properties such as appearance, color, texture, taste and overall acceptability ranged between 7.0 to 9.0. The results related to nutritive value of recipes incorporated with moringa powder at 5 per cent level (per $100 \mathrm{~g}$ ) were having high protein content ranging between 7.0 to $20 \mathrm{~g} / 100 \mathrm{~g}$. The energy, carbohydrate, fat, fiber, total carotenoids, calcium, iron and zinc contents were in the ranges of 255 to $436 \mathrm{kcal} / 100 \mathrm{~g}, 20$ to $56.2 \mathrm{~g} / 100 \mathrm{~g}, 5.5$ to $18.7 \mathrm{~g} / 100 \mathrm{~g}$, 2 to $15.5 \mathrm{~g} / 100 \mathrm{~g}, 482$ to $9146 \mu \mathrm{g} / 100 \mathrm{~g}, 122$ to $183 \mathrm{mg} / 100 \mathrm{~g}, 4.2$ to $6.1 \mathrm{mg} / 100 \mathrm{~g}$ and 1.1 to $3.2 \mathrm{mg} / 100 \mathrm{~g}$. Therefore, incorporating moringa leaf powder in recipes can help in combating malnutrition.
\end{abstract}

Keywords- $\neg$ Malnutrition, Moringa leaf powder, Micronutrients, Adolescent girls

\section{INTRODUCTION}

Malnutrition is world health crisis [1]. Nutrient deficiencies are highly common among adolescent girls as their diets contain low levels of nutrients. According to World Health Organization (WHO), 462 million people across the world are suffering from malnutrition [2]. Nutritional anemia is one of the causes for malnutrition among adolescent girls. Malnutrition occurs due to inadequate supply of nutrients and poor absorption in the body. It is agreed that Food Security does not imply just ensuring adequate energy intake, but also compels that there is adequate consumption of essential micronutrients [3]. The diets of developing countries are lacking in vitamin A, iron, and zinc [4]. Majority of the population are suffering from micronutrient malnutrition. Low consumption of GLV could be a reason for vitamin A and iron deficiency [5]. Moringa leaves are store house of nutrients rich in minerals like copper, potassium, iron, magnesium, zinc and calcium [6]. It works as an effective source of natural antioxidants. Moringa oleifera (fresh) has been used in treating malnutrition. In spite of considerable losses in vitamins, green leafy vegetable powders retained good amounts of proteins, fibre, minerals, fair amounts of ascorbic acid and $\beta$-carotene [7]. The best choice for preserving green leafy vegetables is dehydration. Dehydration is a value addition process [8]. In addition to nutrient concentration, they have more life span than fresh green leafy vegetables. Dehydrated green leafy vegetables are rich in proteins, total phenolics, natural antioxidants, vitamins, minerals and fiber. The major nutrient deficiencies can be taken care of by value addition of GLV powders into commonly consumed and most accepted food products. Incorporation of this moringa leaf in the form of powders can play vital role in prevention of malnutrition and anemia in adolescent girls. Therefore, in the present investigation, an attempt was made to develop moringa leaf powder and standardize few recipes (Pesarattu, Green rice, Bread rolls, muffins and pakodi) by incorporating Moringa leaf powder at 5, 10 and 20 per cent levels. 


\section{International Advanced Research Journal in Science, Engineering and Technology}

Vol. 8, Issue 6, June 2021

DOI: $10.17148 / I A R J S E T .2021 .86114$

\section{EXPERIMENTAL METHODS OR METHODOLOGY}

\subsection{Development of Moringa leaf powder}

Bulk quantities of moringa leaves were bought and were cleaned with cold water to remove the dirt. The roots were trimmed off and the leaves were washed. They were subjected to blanching, a combination of chemicals $(0.5 \%$ potassium metabisulphite $+0.1 \%$ magnesium oxide $+0.1 \%$ sodium bicarbonate) used for blanching is known to have better retention of ascorbic acid when compared to individual chemicals used for blanching [9] at temperatures ranging from 95 to $100^{\circ} \mathrm{C}$ for 5 minutes [10]. The blanched leaves were spread evenly on black tarpaulin sheet and dried in a solar drier at $25 \pm 5^{\circ} \mathrm{C}$ for 24 hours. The dried leaves were finely ground by using pulverizer, sieved, weighed and packed in polyethylene pouched and sealed until further analysis. Moringa leaf powder was presented in Fig. 7.

\subsection{Standardization of recipes}

In the present study, to the recipes of pesarattu, green rice, bread rolls, muffins and pakodi rehydrated moringa leaf powder was added at three different levels, namely 5, 10, 20 percentages and the recipe was standardized.

\subsubsection{Pesarattu}

Pesarattu is a breakfast item made with green gram and rice by soaking for six hours and then grinding coarsely into a batter. Ginger, onions, chillies and rehydrated moringa leaf powder are added to the batter and the batter is spread into pan cakes on a hot shallow frying pan. Fig. 8 shows the standardized pesarattu.

\subsubsection{Green rice}

Green rice is a fragrant, spicy recipe made with mint leaves and some spices-herbs. The green rice was prepared by cooking raw rice in a pressure cooker along with spices, rehydrated moringa leaf powder, coriander and mint paste. The standardized green rice is presented in Fig. 9.

\subsubsection{Bread rolls}

A bread roll is a snack item. Soft- cooked and mashed potatoes, carrots and beans were stir fried along with chopped onions, spices, rehydrated moringa leaf powder and the mixture is stuffed into bread slices which were previously dipped in water and squeezed. The stuffed bread slices were made into balls and deep fried. The standardized bread rolls are presented in Fig. 10.

\subsubsection{Muffins}

Muffin is a bakery product baked in a pan with cup-sized indentations. Muffins were prepared using sugar, butter, refined wheat flour, rehydrated moringa leaf powder, baking powder and baking soda. The standardized chocolate muffins are presented in Fig.11.

\subsubsection{Pakodi}

Pakodi is a spiced fritter snack consumed during snack time along with any hot beverage. They were prepared by mixing Bengal gram flour, rice flour, salt, baking powder, chopped onions, ginger and rehydrated moringa leaf powder. Small quantities of the mixture were dropped in hot oil and deep fried till golden brown. The standardized pakodi is presented in Fig.12.

\section{RESULTS AND DISCUSSION:}

\subsection{Standardization and preparation of value-added products with incorporation of different proportions of green leafy vegetable powders}

The green leafy vegetable powders were incorporated at different levels in a few commonly consumed recipes. In all the recipes the rehydrated moringa leaf powder was incorporated at 5, 10 and 20 percent levels and the recipes were standardized.

\subsection{Organoleptic evaluation}

The standardized recipes incorporated with moringa leaf powder at 5, 10 and 20 per cent levels were subjected to organoleptic evaluation. The mean scores obtained for appearance, texture, flavor, taste and overall acceptability of all the recipes ranged from 7.0 to 9.0. The average acceptance scores for taste decreased markedly at 15 to 20 per cent of leaf mixture incorporation. It is evident that the level of incorporation of powders increased the acceptability had decreased in few recipes. The aroma and mouth feel of the products secured higher scores at the level of 5 per cent but the scores gradually decreased at higher level of incorporation [11].

3.3 Nutritive value of the recipes

The nutritive value of recipes incorporated with Moringa leaf powder at 5 per cent level (per $100 \mathrm{~g}$ ) was calculated and it is found that pakodi and pesarattu found to have rich iron with 6.1 and $5.1 \mathrm{mg} / 100 \mathrm{~g}$. A study also showed an increase in the nutritional value of the products prepared by value addition with drumstick leaves [12]. The moringa muffin depicted an increase in iron $(3.55 \mathrm{mg} / 100 \mathrm{~g})$ [13]. 
International Advanced Research Journal in Science, Engineering and Technology

Vol. 8, Issue 6, June 2021

DOI: $10.17148 / I A R J S E T .2021 .86114$

Table.1. Standardized pesarattu formulations incorporated with moringa leaf powder

\begin{tabular}{|c|c|c|c|c|c|}
\hline \multirow{2}{*}{ S. No } & \multirow{2}{*}{ Ingredients } & \multicolumn{4}{|c|}{ Formulations } \\
\hline & & Control & Formula 1 & Formula 2 & Formula 3 \\
\hline 1 & Green gram dal (g) & 100 & 100 & 100 & 100 \\
\hline 2 & Onions big (g) & 15 & 15 & 15 & 15 \\
\hline 3 & Green chillies (g) & 10 & 10 & 10 & 10 \\
\hline 4 & Ginger (g) & 5 & 5 & 5 & 5 \\
\hline 5 & Moringa leaf powder (g) & 0 & 5 & 10 & 20 \\
\hline 6 & Salt & To taste & To taste & To taste & To taste \\
\hline 7 & Oil (g) & 5 & 5 & 5 & 5 \\
\hline \multicolumn{2}{|c|}{ Cooked weight (g) } & \multicolumn{4}{|l|}{130} \\
\hline \multicolumn{2}{|c|}{ No of servings } & \multicolumn{4}{|l|}{2} \\
\hline \multicolumn{2}{|c|}{ Per serving (g) } & \multicolumn{4}{|l|}{65} \\
\hline
\end{tabular}

Table.2. Standardized green rice formulations incorporated with moringa leaf powder

\begin{tabular}{|c|c|c|c|c|c|}
\hline \multirow{2}{*}{ S. No } & \multirow{2}{*}{ Ingredients } & \multicolumn{4}{|c|}{ Formulations } \\
\cline { 2 - 5 } & & Control & Formula 1 & Formula 2 & Formula 3 \\
\hline 1 & Rice (g) & 100 & 100 & 100 & 100 \\
\hline 2 & Moringa leaf powder (g) & 0 & 5 & 10 & 20 \\
\hline 3 & Mustard (tsp) & 1 & 1 & 1 & 1 \\
\hline 4 & Cumin seeds (tsp) & 1 & 1 & 1 & 1 \\
\hline 5 & Green chillies (g) & 15 & 15 & 15 & 15 \\
\hline 6 & Salt & To taste & To taste & To taste & To taste \\
\hline 7 & Onions chopped (g) & 30 & 30 & 30 & 30 \\
\hline 8 & Dried red chillies (g) & 5 & 5 & 5 & 5 \\
\hline 9 & Mint leaves (g) & 50 & 50 & 50 & 50 \\
\hline 10 & Coriander (g) & 50 & 50 & 50 & 50 \\
\hline 11 & Oil (ml) & 15 & 15 & 15 & 15 \\
\hline Cooked weight (g) & $\mathbf{2 4 0}$ & $\mathbf{2}$ & & \\
\hline No of servings & $\mathbf{1 2 0}$ & \\
\hline Per serving (g) &
\end{tabular}

Table.3. Standardized bread roll formulations incorporated with moringa leaf powder

\begin{tabular}{|c|c|c|c|c|c|}
\hline \multirow{2}{*}{ S. No } & \multirow{2}{*}{ Ingredients } & \multicolumn{5}{|c|}{ Formulations } \\
\cline { 2 - 6 } & & Control & Formula 1 & Formula 2 & $\begin{array}{c}\text { Formula } \\
3\end{array}$ \\
\hline 1 & Carrots (g) & 100 & 100 & 100 & 100 \\
\hline 2 & Onions (g) & 30 & 30 & 30 & 30 \\
\hline 3 & Moringa leaf powder (g) & 0 & 5 & 10 & 20 \\
\hline 4 & Green chillies (g) & 15 & 15 & 15 & 15 \\
\hline 5 & Garam masala (tsp) & $1 / 2$ & $1 / 2$ & $1 / 2$ & $1 / 2$ \\
\hline 6 & Potatoes (g) & 100 & 100 & 100 & 100 \\
\hline 7 & Salt & To taste & To taste & To taste & To taste \\
\hline 8 & Bread (g) & 50 & 50 & 50 & 50 \\
\hline 9 & Oil & $\begin{array}{c}\text { For deep } \\
\text { frying }\end{array}$ & For deep frying & For deep frying & $\begin{array}{c}\text { For deep } \\
\text { frying }\end{array}$ \\
\hline Cooked weight (g) & $\mathbf{1 2 0}$ & \multicolumn{5}{l}{} \\
\hline No of servings & $\mathbf{2}$ & $\mathbf{6 0}$ \\
\hline Per serving (g) &
\end{tabular}


International Advanced Research Journal in Science, Engineering and Technology

Vol. 8, Issue 6, June 2021

DOI: $10.17148 / I A R J S E T .2021 .86114$

Table.4. Standardized muffins formulations incorporated with moringa leaf powder

\begin{tabular}{|c|c|c|c|c|c|}
\hline \multirow{2}{*}{$\begin{array}{l}\text { S. } \\
\text { No }\end{array}$} & \multirow{2}{*}{ Ingredients } & Control & Formula 1 & Formula 2 & Formula 3 \\
\cline { 2 - 5 } & Refined Wheat flour(g) & 60 & 60 & 60 & 60 \\
\hline 2 & Eggs (g) & 1 & 1 & 1 & 1 \\
\hline 3 & Moringa leaf powder (g) & 0 & 5 & 10 & 20 \\
\hline 4 & Sugar Powder & 50 & 50 & 50 & 50 \\
\hline 5 & Butter (g) & 20 & 20 & 20 & 30 \\
\hline 6 & Milk (ml) & 30 & 30 & 30 & 1 \\
\hline 7 & Baking powder (tsp) & 1 & 1 & 1 & $5-6$ \\
\hline 8 & Baking soda (tsp) & 1 & $5-6$ & $5-6$ & Required for \\
topping
\end{tabular}

Table.5. Standardized pakodi formulations incorporated with moringa leaf powder

\begin{tabular}{|c|c|c|c|c|c|}
\hline \multirow{2}{*}{ S. No } & \multirow{2}{*}{ Ingredients } & \multicolumn{4}{|c|}{ Formulations } \\
\cline { 2 - 5 } & Bengal gram flour $(\mathrm{g})$ & 100 & 100 & 100 & 100 \\
\hline 1 & Rice flour $(\mathrm{g})$ & 20 & 20 & 20 & 20 \\
\hline 2 & Water $(\mathrm{ml})$ & 60 & 60 & 60 & 60 \\
\hline 3 & Moringa leaf $(\mathrm{g})$ & 70 & 0 & 0 & 0 \\
\hline 4 & Moringa leaf powder $(\mathrm{g})$ & 0 & 5 & 10 & 20 \\
\hline 5 & Salt & To taste & To taste & To taste & To taste \\
\hline 6 & Onions medium $(\mathrm{g})$ & 30 & 30 & 30 & 30 \\
\hline 7 & Ginger & Pinch & pinch & pinch & pinch \\
\hline 8 & Oil & For frying & For frying & For frying & For frying \\
\hline 9 & & $\mathbf{1 3 0}$ & & \\
\hline Cooked weight $(\mathbf{g})$ & $\mathbf{1}$ & & \\
\hline
\end{tabular}

Table.6. Nutritive value of recipes incorporated with Moringa leaf powder at 5 per cent level (per $100 \mathrm{~g}$ )

\begin{tabular}{|c|c|c|c|c|c|}
\hline Proximates & Pesarattu & Green rice & Breadrolls & Chocolate muffins & Pakodi \\
\hline Protein $(\mathrm{g})$ & 18.4 & 6.7 & 11.3 & 12.5 & 19 \\
\hline Fat $(\mathrm{g})$ & 5.1 & 8.3 & 17 & 18.8 & 16.1 \\
\hline Fiber $(\mathrm{g})$ & 15 & 6.1 & 14.8 & 2.7 & 12 \\
\hline Carbohydrate $(\mathrm{g})$ & 37.6 & 37 & 55 & 45.4 & 48.5 \\
\hline Energy $(\mathrm{kcal})$ & 280 & 255 & 434 & 407 & 433 \\
\hline Total carotenoids $(\mu \mathrm{g})$ & 989 & 9116 & 8645 & 422 & 997 \\
\hline Calcium $(\mathrm{mg})$ & 160 & 154 & 161 & 159 & 126 \\
\hline Iron $(\mathrm{mg})$ & 5.1 & 4.7 & 4.6 & 3.4 & 6.1 \\
\hline Zinc $(\mathrm{mg})$ & 2.3 & 1.1 & 2.5 & 1.2 & 3.2 \\
\hline
\end{tabular}




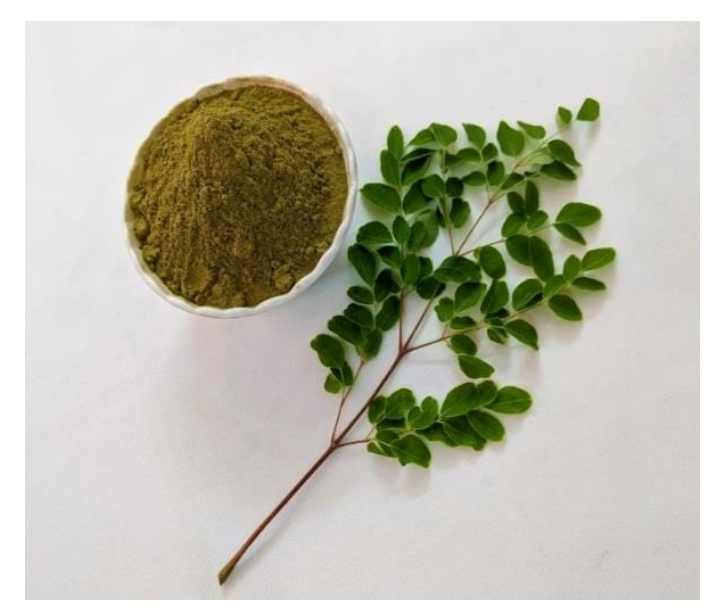

Fig 7. Moringa Leaf Powder

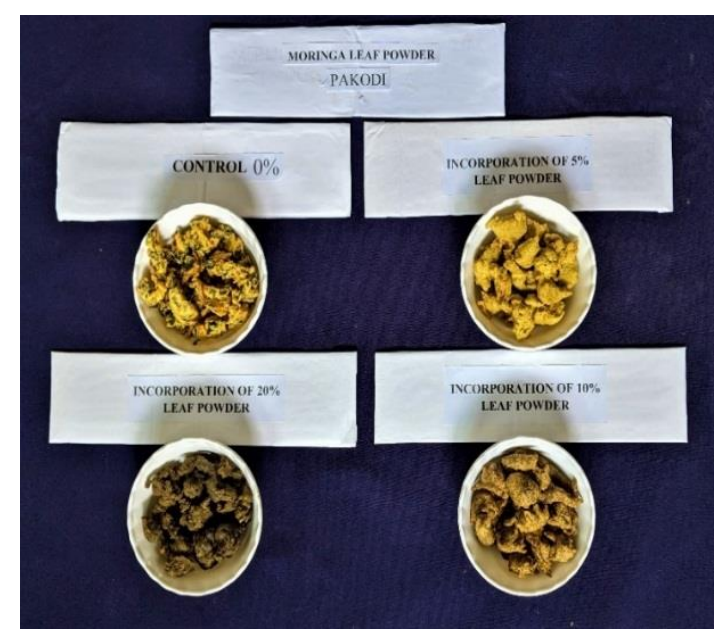

Fig 12. Pakodi

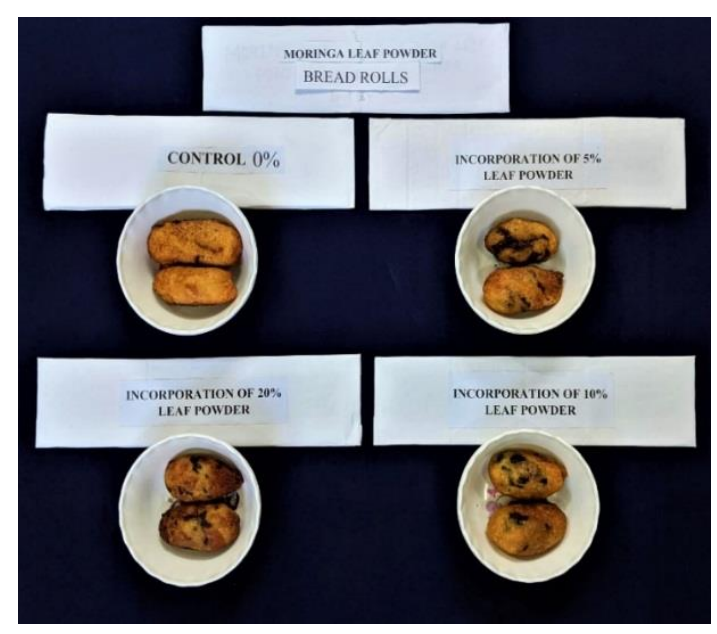

Fig 10. Breadrolls

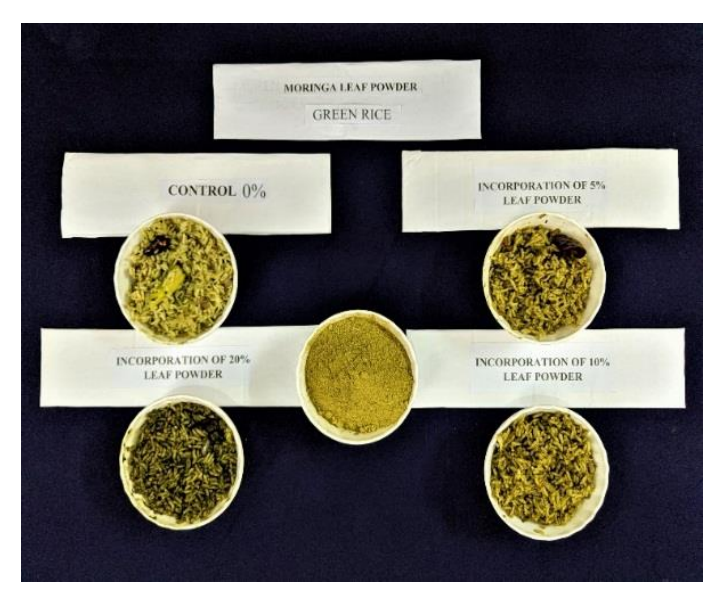

Fig 9. Greenrice

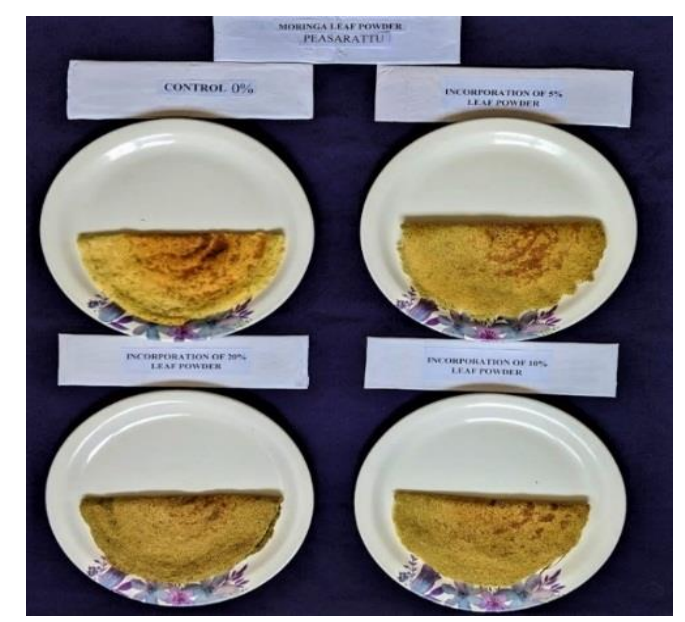

Fig 8. Pesarattu

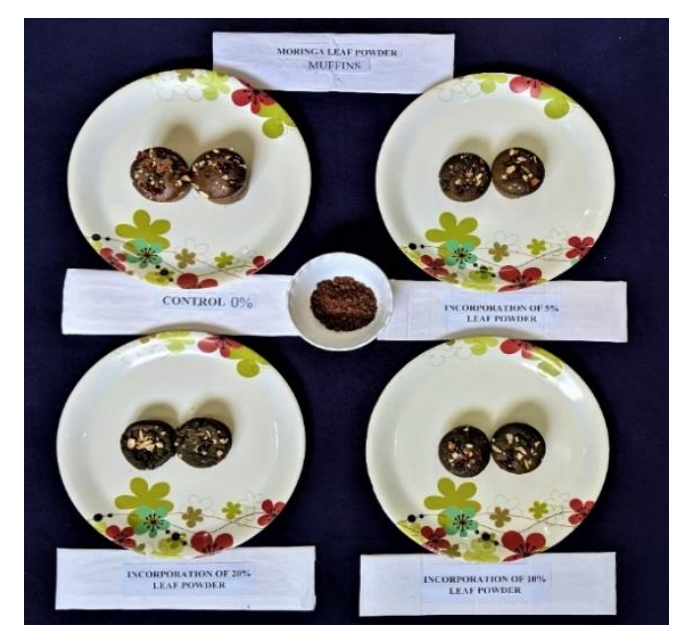

Fig 11. Muffins 


\section{International Advanced Research Journal in Science, Engineering and Technology}

Vol. 8, Issue 6, June 2021

DOI: $10.17148 / I A R J S E T .2021 .86114$

\section{CONCLUSION}

The results of present study added to the knowledge on preparation of micronutrient rich recipes incorporated with moringa leaf powder at acceptable levels, along with information on nutritive values of moringa leaf powder incorporated recipes which can be supplemented to the diets of adolescents for preventing micronutrient malnutrition.

\section{REFERENCES}

1. Malnutrition. Journal of Nutritional Disorders and Therapy, ISSN: 2161-0509, 2020

2. Natisha D. Global Prevalence of Malnutrition: Evidence from Literature published DOI: 10.5772/intechopen.92006. 2020.

3. Nations Standing Committee on Nutrition. Fifth report on the world nutrition situation: nutrition for improved development outcomes Geneva Malnutrition: Causes and Strategies, 2021.

4. GIBSON R. S, Hotz C, Temple L, Yeudall F, Mtitimuni B, and Ferguson E. "Dietary strategies to combat deficiencies of iron, zinc, and vitamin A in developing countries: development, implementation, monitoring, and evaluation." Food and Nutrition Bulletin, pp. 2, 2000.

5. Pallavi Joshi and Beena Mathur. "Development of value added products from the leaf powders of dehydrated less utilized green leafy vegetables." Nutrition and Food Science, pp. 302-309, 2015.

6. Kasolo K.N, Bimenya G.S, Ojok L, Och I. J and Okeng J.W.O. "Phytochemics and uses of Moringa oleifera leaves in Ugandan rural communities." Journal of Medicinal Plant Research, pp. 753-757. 2010.

7. Lakshmi B and Vimala V. "Nutritive value of dehydrated green leafy vegetable powders." Journal of Food Science and Technology, pp. 465-471, 2000.

8. Subhash B.Kakade and Neeha V.S. "Dehydration of Green leafy vegetable: Review." Department of Food Engineering and Technology, ISSN: 2349-6002. 2014.

9. Patil V.R, Kulkarni D.N, Kulkarni K and Ingle U.M. Effect of blanching factors on quality and durability of sun dried and dehydrated fenugreek (Methi). Indian Food Packer, pp. 43-49, 1978.

10. Premavalli K.S, Majumdar T.K and Madhura C.V. "Processing effect on colour and vitamins of green leafy vegetables." Journal of Food Science and Technology, pp. 79-81, 2001

11. Pallavi Joshi and Beena Mathur. "Preparation of value added products from the leaf powders of dehydrated less utilized green leafy vegetables." Journal of Horticulture and Forestry, pp. 223-228, 2010.

12. Nambiar V and Parnami S. "Standardization and Organoleptic Evaluation of Drumstick (Moringa oleifera) Leaves Incorporated into Traditional Recipes. Trees for Life Journal, pp. 2-6, 2008.

13. Srinivasamurthy S, Upasana Y, Surbhi S and Anamika Singh. "Development of muffin by incorporation of dried moringa oleifera (Drumstick) leaf powder with enhanced micronutrient content." International Journal of Food Science and Nutrition, pp. 173-178, 2017. 